\title{
MODAL SOSIAL DALAM GERAKAN LINGKUNGAN: STUDI KASUS DI KAMPUNG GAMBIRAN DAN GONDOLAYU LOR, KOTA YOGYAKARTA ${ }^{1}$
}

Pandhu Yuanjaya ${ }^{2}$

\begin{abstract}
This research discusses about environmental movement initiated by the people of Kampung Gambiran and Kampung Gondolayu Lor, Yogyakarta City. The main argument of this study is that different outcomes by the two environmental movements were affected by the difference in social capital. This is qualitative study. The result of the study shows that the influence of social capital in determining the outcome of environmental movement. Environmental degradation in Kampung Gambiran motivated the local inhabitants to do internal integration and building network outside community. Kampung Gambiran has several achievements, facilities, and activities supported by community fund and outside donors. The movement was also spread by Forsidas Gajah Wong and Merti Kampung. In Kampung Gondolayu Lor, environmental movement was caused by garbage problems and the instruction by the government. The environmental activity without social integration in Kampung Gondolayu Lor resulted in inability to mobilize internal resources and building external network.
\end{abstract}

Key Word: Environmental Movement and Social Capital

\section{ABSTRACT}

Penelitian ini membahas gerakan lingkungan yang dilakukan oleh masyarakat Kampung Gambiran dan masyarakat Kampung Gondolayu Lor Kota Yogyakarta. Argumen pokok dari penelitian ini adalah perbedaan capaian dari kedua gerakan lingkungan dipengaruhi oleh modal sosial. Penelitian ini menggunakan pendekatan kualitatif. Hasil penelitian menunjukkan modal sosial di Kampung Gambiran dapat memobilisasi sumberdaya internal dan membangun jaringan di luar komunitas. Keberhasilan Kampung Gambiran dapat dilihat dari berbagai prestasi, ketersediaan fasilitas dan kegiatan lingkungan (swadaya maupun wujud kerjasama dengan pihak eksternal) serta dapat memperluas gerakan lingkungan melalui Forsidas Gajah Wong dan Merti Kampung. Sedangkan di Kampung Gondolayu Lor, gerakan lingkungan terbentuk lebih karena pakewuh (rasa sungkan) atas instruksi pemerintah tanpa memperhatikan modal sosial. Hal tersebut berdampak pada ketidakmampuan mobilisasi sumberdaya internal dan membangun jaringan eksternal.

Kata Kunci: Masyarakat kampung kota, gerakan lingkungan dan modal sosial

\footnotetext{
1 Penelitian ini didanai oleh In Search of Balance (ISB) Schoolarship kerjasama University of Adger Norway dan Universitas Gadjah Mada

2 Staf Pengajar, Jurusan Ilmu Adminsitarsi Negara, Fakultas Ilmu Sosial, Universitas Negeri Yogyakarta, email: pandhu13yuan@gmail.com
} 


\section{PENDAHULUAN}

Kajian tentang ilmu administrasi publik kontemporer mengalami pergeseran paradigma dari government ke governance. Dalam studi tentang governance, teori-teori administrasi publik tidak lagi dibatasi oleh birokrasi dan lembaga pemerintah, tetapi mencakup semua bentuk organisasi yang misi utamanya mewujudkan publicness (Haque, 2001; Dwiyanto, 2004; Pesch, 2008; Moulton, 2009). Organisasi semacam ini tidak lain adalah organisasi yang peduli pada shared problem dan beroperasi untuk mencapai public purpose. Pergeseran paradigma tersebut sangat relevan bila dikaitkan dengan isuisu kontemporer yang tidak bisa dilihat hanya dari sudut pandang internal birokrasi. Terlebih lagi, esensi dari kajian ilmu administrasi publik sebenarnya mengintepretasikan nilai dan preferensi dari masyarakat, komunitas dan warga negara secara keseluruhan (Bourgon, 2007). Implikasinya jelas, ilmu administrasi publik tidak lagi terlalu berorientasi kepada aktivitas negara, tetapi menjadi oleh, untuk dan kepada masyarakat (Utomo 2009).

Teorisasi tentang kebijakan publik yang dikelola oleh para pejabat pemerintah pada akhirnya dituntut konsisten dengan pergeseran paradigma ilmu administrasi publik seperti yang dijelaskan sebelumnya. Mainstream kajian tentang kebijakan publik di Indonesia selama ini memang cenderung memahami proses kebijakan sebagai proses internal pemerintah. Padahal, ketika proses kebijakan publik yang identik dengan proses birokrasi pemerintah maka konsep partisipasi publik dalam pengambilan keputusan yang banyak dituntut para penganjur demokrasi akan menjadi selogan kosong (Santoso, Hanif dan Gustomy, 2004). Kajian penelitian ini mengenai gerakan lingkungan dalam Program Kampung Hijau memperlihatkan kesulitan praktis maupun teoritis ketika sudut padang mainstream kebijakan publik tersebut sebelumnya dipertahankan. Hal ini karena Program Kampung Hijau hanya sebagai naungan pelembagaan gerakan lingkungan sehingga keberhasilan program sepenuhnya tergantung pada kapasitas gerakan lingkungan.

Sifat publicness dalam penelitian ini melekat pada komunitas gerakan lingkungan yang berusaha menyelesaikan degradasi lingkungan (public interest). Pemerintah, melalui Badan Lingkungan Hidup (BLH), hanya melakukan pendampingan terhadap masyarakat, atau pemerintah sebagai katalisator (Osborne dan Gaebler, 1996). Melalui perspektif gerakan lingkungan, proses kebijakan dipahami dari kerangka pikir masyarakat 
yang selama ini hanya sebagai alamat kebijakan, bukan pelaku kebijakan. Hal ini penting karena keberhasilan suatu kebijakan sosial adalah hasil yang dicapai komunitas, bukan merupakan produk dari kebijakan yang dibuat pemerintah (Cronbach, 1985). Dengan adanya perspektif dari dua sisi komunitas masyarakat, Kampung Gambiran sebagai gerakan lingkungan yang masih konsisten dan Kampung Gondolayu Lor sebagai gerakan lingkungan yang telah mengalami penurunan, diharapkan adanya alternatif kebijakan sebagai upaya pengelolaan lingkungan hidup yang holistis dan berkelanjutan.

Masyarakat Kota Yogyakarta khususnya yang tinggal di bantaran sungai, selalu menderita di musim penghujan (bulan November-Februari). Ancaman banjir, wabah demam berdarah, dan penurunan kesehatan telah menjadi rutinitas yang tidak pernah tuntas terselesaikan. Laporan Status Lingkungan Hidup Daerah (SLHD) Kota Yogyakarta 2012 memperkirakan total kerugian akibat banjir di musim penghujan sebesar 2,5 miliar rupiah dan jumlah pengungsi sebanyak 2.070 jiwa. Kutanegara (2014) menyoroti fungsi sungai di Kota Yogyakarta telah berubah menjadi drainase raksasa atau seperti tempat pembuangan sampah dan limbah masyarakat sebagai penyebab terjadinya berbagai masalah lingkungan.

Bila kebijakan lingkungan Pemerintah Kota Yogyakarta dilihat lebih mendalam, seperti: program Prokasih (Program Kali Bersih), penataan RTH (Ruang Terbuka Hijau) dan program swakelola sampah, dapat dikatakan kebijakan-kebijakan tersebut hanya project and reward oriented. Masyarakat ditempatkan hanya sebagai objek dari program lingkungan. Implikasinya jelas, kebijakan yang demikian akan memberikan hasil yang tidak berkelanjutan atau bahkan mengalami kegagalan. Lane (2003) mengatakan pentingnya reposisi peran masyarakat, tidak hanya sebagai objek terkena dampak, tapi juga menjadi bagian integral yang tak terpisahkan dalam pengelolaan lingkungan. Selain itu, upaya yang dilakukan masyarakat merupakan titik sentral pengelolaan lingkungan kota utamanya berawal dari bantaran sungai (Laurens, 2012).

Gerakan lingkungan oleh masyarakat muncul sebagai tanggapan atas kegagalan kebijakan lingkungan pemerintah kota dalam mengatasi dampak negatif dari degradasi lingkungan. Program Kampung Hijau yang diperkenalkan oleh Pemerintah Kota Yogyakarta pada tahun 2007 lebih jauh menunjukkan gerakan lingkungan dapat 
merubah kebijakan lingkungan. Dari seluruh komunitas yang menerapkan Kampung Hijau, Kampung Gambiran dan Kampung Gondolayu Lor menjadi komunitas kampung dengan capaian paling memuaskan baik dari aspek prestasi, kegiatan, infrastruktur dan peran aktif masyarakat.

Setelah tujuh tahun (2014), gerakan lingkungan Kampung Hijau Gondolayu Lor berdasarkan evaluasi oleh BLH menyatakan mulai adanya penurunan gerakan. Hal ini berbeda dengan Kampung Hijau Gambiran yang berhasil merubah kondisi lingkungan hidup. Keberhasilan dan kegagalan Kampung Hijau menunjukkan adanya faktor-faktor yang mempengaruhi dinamika gerakan lingkungan. Broadbent dan Brockman (2011) mengatakan gerakan lingkungan muncul tidak hanya dipengaruhi oleh refleksi sosial dari masyarakat, namun juga tercipta dari aktor dalam struktur politik. Suharko (2006) memberikan pandangan yang tegas mengenai dinamika perjuangan aktor dalam gerakan masyarakat yang sangat tergantung pada sumberdaya internal dan aspek-aspek eksternal. Sumberdaya internal yang dimaksudkan adalah ideologi diri, nilai-nilai bersama, komitmen, kemampuan (pengetahuan, pendanaan, waktu dan lain-lain) serta esprit de corps. Sedangkan aspek-aspek eksternal, meliputi dukungan pemerintah, kodisi sosial politik, strategi pembangunan dan lain-lain.

Tanpa mengabaikan faktor-faktor eksternal yang mempengaruhi gerakan masyarakat, dinamika yang terjadi dalam gerakan ini banyak dipengaruhi faktor internal atau yang biasa disebut modal sosial. Broadbent dan Brookman (2011) mengatakan mobilisasi sumberdaya melalui modal sosial sangat berpengaruh pada keberhasilan gerakan masyarakat. Botetzagias dan Schuur (2012) menjelaskan nilai dan kepercayaan merupakan sumberdaya potensial untuk dimobilisasi dalam gerakan lingkungan, potensi tersebut akan mendorong terbentuknya identitas bersama, partisipasi dan perluasan jaringan baik secara internal maupun eksternal. Modal sosial juga penting dikaji lebih dalam karena dapat menjadi stimulus keberhasilan sebuah kebijakan (Field, 2014).

\section{METODE}

Penelitian ini menggunakaan pendekatan studi kasus yang dilakukan pada bulan April hingga September 2014. Informasi dalam studi ini dikumpulkan malalui wawancara mendalam, observasi mengenai aktivitas khususnya kegiatan lingkungan, Focus Group Discussion (FGD), dan telaah dokumentasi. 
Observasi dilakukan dengan menetap selama dua minggu di masingmasing kampung, dan dilakukan saat komunitas menyelenggarakan kegiatan atau masyawarah, seperti: acara perkumpulan Forsidas Gajah Wong dan Ngobar Ngabir di Kampung Gambiran serta kegiatan peringatan 17 Agustus dan Code's Night Festival di Kampung Gondolayu Lor. Wawancara mendalam (in-depth interviewing) sebanyak 23 orang yang terdiri dari: pengurus Kampung Hijau dari BLH (Badan Lingkungan Hidup), WALHI (Wahana Lingkungan Hidup), Ketua Pengurus Forsidas Gajah Wong dan Pamerti Code, Staf Kelurahan Pandeyan dan Cokrodiningratan, dan Pengurus RW (Rukun Warga) dan RT (Rukun Tetangga), sedangkan snowball metode dilakukan terhadap 18 masyarakat di kedua kampung.

FGD dengan pengurus komunitas Kampung Gambiran meliputi: Ketua RT dan RW serta Pokja Lingkungan, dan Pengurus Forsidas Gajah Wong meliputi Ketua dan Anggota. FGD di Kampung Gondolayu Lor tidak dapat diselenggarakan karena masyarakat menolak adanya pembahasan mengenai kegiatan lingkungan setelah terjadinya konflik. Selama proses penelitian, peneliti juga melakukan telaah dokumendokumen, yaitu: Perda Lingkungan Hidup Kota Yogyakarta, Buku Status
Lingkungan Hidup Derah (SLHD) Kota Yogyakarta, Buku Monografi Kampung (RW).

Analisis dalam penilitian ini secara khusus melihat bekerjanya modal sosial dalam gerakan lingkungan. Modal sosial menjadi indikator dan syarat yang dibutuhkan dalam tindakan kolektif/ gerakan (collective action) (Grootaert dan Bastelaer, 2001; Edwards, 2013). Pretty dan Ward (2001) lebih jauh telah membangun tipologi untuk menggambarkan evolusi modal sosial dalam gerakan lingkungan melalui tiga tahap, yaitu reactive-dependence, realization-independence dan awarenessinterdependence. Tahap-tahap modal sosial ini sesuai apabila dihubungkan dengan empat tahap gerakan masyarakat menurut Christiansen (2009) yang telah dijelaskan sebelumnya. Lebih lanjut,

Gerakan sosial lahir dari aksi terhadap sesuatu yang tidak diinginkan rakyat atau menginginkan perubahan kebijakan (Giddens 2004; Schwartz, 2010; Sztompka, 2011). Gerakan lingkungan yang menjadi fokus penelitian ini didasari oleh gerakan sosial pada isu-isu lingkungan telah menjadi peluang dari trend global dengan memobilisasi perlawanan terhadap eksploitasi sumber daya alam dan kerusakan lingkungan serta mendukung penegasan kembali hak-hak tradisional dan kualitas lingkungan di 
tingkat masyarakat (Sridahar, 2010; Cohen, et al., 2012;). Gerakan lingkungan merupakan mobilisasi kelompok lokal/ komunitas masyarakat lokal ketika masyarakat menemukan bahwa kehidupan mereka terancam kerusakan lingkungan dan tidak mendapatkan hak dengan pantas (Earle, 2011).

Penelitian ini akan membahas empat tahapan gerakan sosial menurut Herbert Blumer, yaitu: ketidakpuasan sosial (social ferment), antusiasme orang banyak (popular excitement), formalisasi (formalization), dan pelembagaan (institutionalization) (Della Porta \& Diani 2006). Sedangkan Christiansen (2009), menjelaskan keempat tahap gerakan adalah tahap kemunculan (emerge), tahap koalisi (coalescene), tahap formalisasi (bureaucratization), dan tahap surut (decline). Sebagai upaya menghindari bias dalam penggunaan istilah serta mengacu dua pendapat tersebut, penelitian ini menggunakan istilah "hasil" pada tahap keempat. Tahapan tersebut dijelaskan sebagai berikut:

1. Tahap pertama yaitu kemunculan, individu merasa tidak puas dan tidak nyaman dengan keadaan yang ada, baik karena disebabkan kebijakan atau kondisi sosial tertentu, tetapi mereka tidak mengambil tindakan dan bergerak secara individu
2. Tahap kedua yaitu koalisi, perasaan ketidakpuasan menjadi kolektif dan mulai mengorganisir dan membuat strategi.

3. Tahap ketiga yaitu formalisasi, gerakan telah memiliki karakteristik sebagai organisasi.

4. Tahap keempat yaitu hasil, berupa: represi, kooptasi, kekeberhasilan, dan kegagalan.

Sedangkan terminologi modal sosial sangat erat kaitannya dengan masyarakat atau komunitas. Masyarakat atau komunitas diartikan sebagai sekelompok orang yang berkumpul dengan alasan yang berbeda-beda, yaitu dengan alasan geografi, ekonomi, sosial, politik/ adminitrasi dan alasan yang lain (UNEP-IETC, 2003). Komunitas tersebut dapat menjadi bagian dari konsep diri seseorang dan merupakan aspek penting sebagai sudut pandang atau berperilaku (Ife dan Tesoriero, 2008). Terdapat beragam metode dalam mengukuran modal sosial menggunakan unsur-unsur modal sosial yang dapat disesuaikan dengan kondisi lokal dan tujuannya (Narayan dan Cassidy 2001). Untuk melihat modal sosial dalam komunitas, penelitian ini menggunakan enam unsur pembentuk modal sosial (Hasbullah, 2006), dijelaskan sebagai berikut:

1. Kepercayaan, merupakan hubunganhubungan sosialnya yang didasari 
oleh perasaan yakin bahwa orang lain akan melakukan sesuatu seperti yang diharapkan.

2. Jaringan, adalah kapasitas yang ada dalam kelompok masyarakat untuk membangun sejumlah asosiasi berikut membangun jaringan.

3. Resiprositas, yaitu saling tukar menukar kebaikan antar individu dalam suatu kelompok atau antar kelompok.

4. Norma sosial, berperan dalam mengontrol bentuk-bentuk perilaku yang dalam masyarakat.

5. Nilai-nilai sosial, dimaknai sebagai suatu ide yang telah turun menurun dianggap benar dan penting oleh anggota kelompok masyarakat.

6. Tindakan yang proaktif, merupakan suatu keinginan yang kuat dari anggota untuk tidak saja berpartisipasi tetapi senantiasa mencari jalan bagi keterlibatan mereka dalam suatu kegiatan masyarakat.

\section{HASIL DAN PEMBAHASAN}

\section{Gerakan Lingkungan di Kampung} Gambiran dan Gondolayu Lor

1. Gerakan Lingkungan di Kampung Gambiran

Gerakan lingkungan yang dilakukan masyarakat Kampung Gambiran tidak dapat dipisahkan dengan degradasi lingkungan dan bencana yang ditimbulkannya. Pada kurun waktu Desember 2004 hingga Februari 2005 (musim penghujan) di Kampung Gambiran terjadi bencana banjir yang menyebabkan banyak kerugian, antara lain: hancurnya saluran pelimpah, taman dan infrastruktur terutama yang ada di RT 31 seluas $\pm 500 \mathrm{~m}^{2}$, serta mengakibatkan rusaknya beberapa rumah warga. Tidak hanya banjir, tahun 2005 menjadi puncak dari degradasi lingkungan, ditandai dengan terjangkitnya sebagian besar warga dari penyakit demam berdarah, namun masyarakat masih menganggap sebagai masalah pribadi dan juga diselesaikan pada ranah privat. Usaha mempersatukan masyarakat dimulai dengan menghilangkan culture gap atau kesenjangan budaya dalam masyarakat.

Masyarakat kemudian berinisiatif untuk mengadakan musyawarah yang disebut dengan "rembug warga". Masyarakat secara kolektif berkerja bersama memperbaiki lingkungan meskipun tidak terlembaga. Pendampingan dilakukan oleh BLH Kota Yogyakarta dan WALHI (kampanye lingkungan Maret 2005-Mei 2006 dan pendampingan intensif Juni 2006-April 2007). Berdasarkan evaluasi BLH dan WALHI, kemandirian warga gambiran telah menunjukkan kemampuan suatu komunitas dalam memberdayakan diri 
sendiri di bidang lingkungan. Pada bulan April 2007, gerakan lingkungan terintegrasi dalam Program Kampung Hijau sebagai sarana institusionalisasi gerakan.

Perubahan kondisi fasilitas lingkungan diantaranya: infrastruktur mitigasi bencana, ruang publik/ ruang terbuka hijau $(\mathrm{RTH})$, pengelolaan mata air, tamanisasi dan penghijauan, bank sampah "asri”, sanitasi, balai pertemuan, pengembangan energi alternatif (biogas dan energi surya). Beberapa kegiatan lingkungan diantaranya; Peringatan Hari Bumi, Ulang Tahun WALHI, wayangan (pertunjukan wayang) rutin, Gerakan Hemat Air, Seminar Nasional Lingkungan, studi banding, penelitian dan lain sebagainya. Beberapa penghargaan/ prestasi yang dicapai sebagai berikut: Juara Lomba Kampung Hijau Tingakat Provinsi DIY (2007), Juara Umum Lomba Kali Bersih Kota Yogyakarta (2008), Juara Green and Clean Provinsi DIY (2008), Juara Walikota Award Pengelolaan Ruang Terbuka Hijau (2009), Rintisan ProKlim (Kampung Iklim) Kementerian Lingkungan Hidup (2012), Juara Indonesia MDG's Award (2013). Pada tahun kelima (2012), Kampung Gambiran dapat meluaskan gerakan lingkungan dengan membentuk Forsidas Gajah Wong dan menyelenggarakan ritual Merti Kampung Gambiran.
2. Gerakan Lingkungan di Kampung Gondolayu Lor

Masyarakat Kampung Gondolayu Lor telah memulai mengelola sampah sejak pertengahan tahun 2005. Kegiatan ini berawal dari penyampaian ide dalam penyuluhan yang dilakukan oleh Dinas Kebersihan, Keindahan dan Pemakaman (sejak tahun 2006 menjadi BLH) pada awal tahun 2005. Setelah melewati tahap sosialisasi dan studi banding ke Desa Sukunan, masyarakat kampung Gondolayu Lor antusias dan tertarik untuk melaksanakan kegiatan yang sama. Hal ini karena masalah sampah tidak pernah terselesaikan dengan berbagai program pemerintah. Hasil dari musyawarah antara masyarakat dan pemerintah dengan dikeluarkannya SK Pim.Keg. No. 24/KSD/KEP/2005 sebagai daerah percontohan (pilot project) kegiatan pemilahan sampah di Kota Yogyakarta.

Seiring dengan kompleksitas dari degradasi lingkungan, gerakan lingkungan masyarakat Gondolayu Lor masuk ke program Kampung Hijau pada Januari 2007. Sebagai wadah gerakan lingkungan ini, penduduk Kampung Gondolayu Lor kemudian membentuk Paguyuban Golong Gotro. Dengan demikian, gerakan lingkungan melalui penghijauan, pengelolaan sampah dan peningkatan kesadaran lingkungan sesungguhnya merupakan kebutuhan masyarakat 
mengenai kualitas lingkungan yang semakin mendesak. Selain itu lebih disebabkan pakewuh (rasa sungkan) atas instruksi aparat pemerintah. Periodisasi gerakan lingkungan di Kampung Gambiran dijelaskan sebagai berikut:

Kegiatan lingkungan di Kampung Gondolayu Lor sebagian besar dalam wujud pengelolaan sampah dan penghijauan kampung. Masyarakat Kampung Gondolayu Lor hanya menunggu program atau ide dari BLH, selain itu mengandalkan "ulu-ulu kali" (petugas kebersihan Sungai Code). Kegiatan lingkungan yang dilakukan dan terdokumentasikan di Kampung Gondolayu Lor sangat minim, hasil observasi menunjukkan hanya kegiatan PKK yang bersifat rutin dan dilakukan di hari libur. Hanya capaian PKK yang memuaskan seperti Juara Apresiasi Gerakan Perilaku Hidup Bersih dan Sehat (PHBS) 2013, menjadi perwakilan Pemerintah Kota Yogyakarta dalam berbagai pelatihan. Pamerti Code yang dibentuk oleh berbagai komunitas peduli Sungai Code pada tahun 2012 juga tidak serta merta membuat Komunitas Kampung Gondolayu Lor terintegrasi didalamnya.

3. Perbandingan

Gerakan Lingkungan Kampung Hijau Gambiran dan Gondolayu Lor
Pemaparan pada pembahasan sebelumnya menunjukkan adanya perbedaan capaian dari kedua gerakan lingkungan tersebut tidak hanya dari sisi prestasi (penghargaan), namun juga dapat dilihat dari pembangunan fasilitas penunjang yang dibangun, rutinitas kegiatan lingkungan, relasi dengan stakeholder eksternal dan tentunya kemampuan komunitas mengembangkan diri serta memperluas gerakan lingkungan.

Padahal, dengan sumberdaya dan dukungan pemerintah yang sama berupa keleluasaan penyampaian ide dan akses terhadap sumberdaya, seharusnya tidak ada perbedaan hasil yang signifikan dari kedua gerakan lingkungan tersebut. Untuk melihat fakta menarik ini, dapat dilihat mengunakan tahapan gerakan dikedua kampung, dijelaskan pada Tabel 1.

\section{Modal Sosial dalam Gerakan}

\section{Lingkungan Kampung Gambiran dan}

\section{Gondolayu Lor}

Bagian ini mengidentifikasi keenam unsur-unsur modal sosial kepercayaan, jaringan sosial, saling tukar kebaikan, norma, nilai-nilai dan tindakan yang proaktif di kedua kampung. Identifikasi di kedua kampung tersebut menunjukkan modal sosial sangat menentukan capaian gerakan lingkungan baik secara internal komunitas maupun jaringan komunitas dengan pihak 
Tabel 1. Perbandingan Gerakan Lingkungan

\begin{tabular}{|c|c|c|}
\hline Tahapan & Kampung Gambiran & Kampung Gondolayu Lor \\
\hline Kemunculan & $\begin{array}{l}\text { - Pencarian masalah dan solusi secara } \\
\text { individu. } \\
\text { - Pengajuan proyek infastruktur yang } \\
\text { ditolak berbagai lembaga }\end{array}$ & $\begin{array}{l}\text { - Kondisi kampung yang kumuh } \\
\text { dan pakewuh atas instruksi } \\
\text { pemerintah (Ide pengelolaan } \\
\text { sampah dari pemerintah) }\end{array}$ \\
\hline Ko & $\begin{array}{l}\text { - Upaya mengatasi kesenjangan budaya. } \\
\text { - Seluruh masyarakat mengikuti Rembug } \\
\text { Warga, mulainya tindakan kolektif } \\
\text { (penghijauan, kerjabakti dan } \\
\text { pengelolaan sampah dan pendampingan } \\
\text { intensif BLH dan LSM. }\end{array}$ & $\begin{array}{l}\text { - Musyawarah tokoh masyarakat, } \\
\text { yang diikuti dengan sosialisasi } \\
\text { dan studi r banding } \\
\text { (pendampingan BLH dan LSM) } \\
\text { - Pilot project pengelolaan } \\
\text { sampah }\end{array}$ \\
\hline Forn & $\begin{array}{l}\text { - Deklarasi Komunitas Kampung Hijau } \\
\text { (April 2007) } \\
\text { - Perluasan jaringan kerjasama dengan } \\
\text { eksternal }\end{array}$ & $\begin{array}{l}\text { - Deklarasi Komunitas Kampung } \\
\text { Hijau (Januari 2007) } \\
\text { - Membentuk paguyuban Golong } \\
\text { Gotro (internal) }\end{array}$ \\
\hline Hasil & $\begin{array}{l}\text { - Keberhasilan melakukan pembangunan } \\
\text { infrastruktur dan kegiatan lingkungan } \\
\text { (swadaya dan kerjasama) } \\
\text { - Berbagai prestasi dan penghargaan } \\
\text { - Perluasan pengaruh gerakan (inisiator } \\
\text { Forsidas Gajah Wong dan Merti } \\
\text { Kampung) }\end{array}$ & \begin{tabular}{|lr} 
- Kegiatan hanya berupa & bengelolaan sampah \\
pank & \\
Sampah) & \\
- Sejak 2009 tidak ada prestasi. \\
- Tidak terintegrasi dengan \\
komunitas Sungai Code \\
(Pemerti Code)
\end{tabular} \\
\hline
\end{tabular}

Sumber: Hasil Penelitian 2014

eksternal. Pengaruh internal dari modal sosial di Kampung Gambiran dapat memobilisasi dan mengakses sumberdaya masyarakat seperti, tenaga, waktu, dana, pengetahuan, pengalaman, loyalitas dan sebagainya. Sedangkan Kampung Gondolayu Lor, modal sosial tidak dapat memobilisasi sumberdaya internal. Pengaruh eksternal terlihat dari kemampuan masyarakat Kampung Gambiran dalam menjalin kerjasama yang luas dengan berbagai stakeholder, hal ini tidak terjadi di Kampung Gondolayu Lor yang hanya tergantung dari BLH.

Hasil penelitian menunjukkan kepercayaan menjadi faktor utama dalam modal sosial. Kepercayaan antar masyarakat Kampung Gondolayu Lor sangat rendah ditunjukkan dengan terjadinya konflik akibat ketidakpercayaan (distrust) antar masyarakat dan pengurus dalam mengelola proyek-proyek kerjasama dengan BLH. Sedangkan di Kampung Gambiran, masyarakat sangat menjaga kepercayaan tidak hanya secara internal, namun juga terjaga dalam menjalin kerjasama dengan pihak eksternal melalui berbagai kerjasama multi years yang berkelanjutan.

Perbedaan kualitas modal sosial dari kedua kampung yang paling mencolok adalah jaringan sosial. Tidak 
banyak perbedaan apabila dilihat dari ketersediaan jaringan internal yang berpengaruh pada gerakan lingkungan yaitu Komunitas Kampung Hijau dan PKK. Kemampuan jaringan internal di Kampung Gambiran ditunjukkan berbagai aktivitas dapat dilakukan baik pembangunan fasilitas umum dan kegiatan lingkungan dilakukan secara swadaya, yang berbeda dengan Kampung Gondolayu Lor yang hanya dapat mengerjakan pengelolaan sampah dan kegiatan rutin lainnya. Masyarakat Kampung Gambiran juga membangun jaringan eksternal dengan berbagai pihak seperti lembaga pemerintah (BLH, Diskimpraswil, Bappeda, Kementerian Lingkungan Hidup dan sebagainya), Lembaga Swadaya Masyarakat (Walhi dan SHIND), berbagai CSR dari perusahaan (misalnya: Unilever), lembaga pendidikan (UGM dan UTY), Media, dan memperluas pengaruh gerakan lingkungan dengan terbentuknya Forsidas dan Merti Kampung. Sedangkan Kampung Gondolayu Lor tidak mampu mengembangkan jaringan eksternal. Hal ini dijelaskan oleh Sekretaris RW 10, sebagai berikut:

"Sampai sejauh ini masih sama BLH dan beberapa CSR perusahaan. Untuk bantuan CSR itu, ya tentu biasanya BLH yang membawa kesini, siapa lagi mas, yang mengurus itu-itu saja."
(Wawancara pada tanggal 23 Agustus 2014)

Resiprositas atau timbal balik bagi masyarakat Kampung Gambiran bermakna terciptanya lingkungan yang baik, perubahan perilaku, kebiasaan dan juga sosial ekonomi dari pengelolaan lingkungan. Di sisi lain, Komunitas Kampung Gondolayu Lor hanya terjadi kegiaan yang bersifat ritual turun menurun (tahlilan, sayan dan upacara keagamaan). Selain itu, masyarakat Kampung Gondolayu Lor berorientasi pada keuntungan ekonomi dari proyek-proyek lingkungan.

Konsistensi mematuhi norma dan nilai lingkungan, di Kampung Gambiran menjadi pedoman dalam berperilaku sesuai dengan kaidah lingkungan, berbeda di Kampung Gondolayu Lor yang tidak memiliki norma dan nilai lingkungan. Tindakan yang proaktif dapat dilihat dari partisipasi kedua kampung yang sangat berbeda. Kegiatan lingkungan Kampung Gambiran selalu diiringi partisipasi yang tinggi dari masyarakatnya baik berupa tenaga, dana, waktu, loyalitas dan lain sebagainya serta dari capaian yang telah diperoleh menunjukkan adanya inovasi dan inisiatif dalam masyarakat. Di Kampung Gondolayu Lor partisipasi dilakukan oleh sebagian warga dan hanya sebatas pemilahan sampah serta membuktikan tidak adanya inovasi serta 
inisiatif dari masyarakat untuk membangun jaringan dan mengusulkan kegiatan kepada pihak eksternal.

\section{Refleksi Teoritis}

Analisa pada bagian ini bukan ditujukan untuk menguji fakta empiris temuan lapangan dengan teori, tetapi menjelaskan fenomena secara teoritis dalam bingkai gerakan lingkungan dan modal sosial, serta implikasinya pada kajian Administrasi Publik khususnya teori kebijakan publik.

Belakangan ini teori-teori administrasi telah mengalami pergeseran. Udo Pesch dalam jurnalnya The Publicness of Public Administration (2008) menunjukkan perubahan paradigma yang luar biasa dalam perkembangan kajian administrasi merujuk pada kata publicness. Dwiyanto (2004) menjelaskan dalam reorientasi administrasi publik, tidak lagi terbatas pada lembaga pemerintah, tetapi meliputi semua organisasi yang misi utamanya mewujudkan publicness. Organisasi semacam ini tidak lain adalah organisasi yang peduli pada shared problems dan beroperasi untuk mencapai public purposes. Artinya, konsep publik dalam administrasi publik tidak lagi diartikan secara kelembagaan tetapi lebih pada orientasi dan nilai-nilai publicness. Pada isu lingkungan yang diajukan dalam penelitian ini, sifat publicness juga melekat pada komunitas gerakan lingkungan yang berusaha menyelesaikan degradasi lingkungan yang merupakan public interest. Akhirnya, peran pemerintah dalam Program Kampung Hijau hanya sebagai katalisator, pemegang control (pengarah) bukan sebagai pelaku usaha (pelaksana) (Osborne \& Gaebler, 1996).

Pemikiran administrasi negara tidak lagi dapat bersifat inward looking (hanya berorientasi kedalam jajaran birokrasi pemerintahan), melainkan justru harus berorientasi ke masyarakat (Santoso, Hanif dan Gustomy, 2004). Implikasinya jelas, proses kebijakan publik para pejabat pemerintah dan penelitian kebijakan dituntut konsisten dengan pergeseran tersebut. Melalui perspektif gerakan lingkungan, proses kebijakan dipahami dari kerangka pikir masyarakat yang selama ini hanya sebagai alamat kebijakan, bukan pelaku kebijakan. Hasil penelitian gerakan lingkungan Kampung Hijau menggunakan pendekatan tersebut sebelumnya dapat menjawab esensi dari kebijakan yaitu apa yang dilakukan masyarakat, pemenuhan hak masyarakat dan perubahan sosial.

Gerakan lingkungan di kedua kampung tersebut apabila menggunakan empat tahapan gerakan masyarakat menurut Cristiansen (2009) dapat 
memberikan gambaran perbedaan mengenai proses dan hasil yang dicapai. Dari proses, yang membedakan adalah pada tahap kedua (koalisi), masyarakat Kampung Gambiran memilih untuk mengintegrasi seluruh elemen masyarakat, sedangkan masyarakat Kampung Gondolayu Lor memilih untuk langsung mengelola sampah. Hal ini berimplikasi pada kesiapan internal dan kekuatan membangun jaringan yang dimiliki oleh kedua kampung. Di Kampung Gambiran, masyarakat berhasil merubah kondisi, sedangkan Kampung Gondolayu Lor kembali menjadi kampung yang kumuh.

Temuan tersebut sekaligus mengkritisi pandangan Aditjondro (2003) bahwa sebagai negara berkembang, di Indonesia hanya ada satu komponen saja yang berpengaruh dalam pengelolaan lingkungan yaitu gerakan lingkungan oleh institusi pemerintah (the institutional environmental movement organization) seperti BLH atau Kementerian Lingkungan Hidup. Gerakan lingkungan yang dilakukan masyarakat di Kota Yogyakarta membuktikan masyarakat mampu secara mandiri mengelola lingkungan. Walaupun secara lebih luas gerakan ini tidak dapat menyelesaikan isu pemanasan global yang melibatkan kegiatan industri dan kebijakan sebuah negara, namun dalam skala masalah lingkungan menurut Inoguchi, Newman, dan Paoletto (2003), gerakan lingkungan ini telah dapat menyelesaikan masalah lingkungan pada skala komunitas dan lebih luas pada kota/ daerah.

Hasil penelitian menunjukkan modal sosial sangat menentukan keberhasilan gerakan lingkungan. Identifikasi terhadap modal sosial melalui unsur-unsur modal sosial menurut Hasbullah (2006) yaitu kepercayaan, jaringan sosial, resiprositas atau timbal balik, norma sosial, nilai sosial dan tindakan yang proaktif menunjukkan di Kampung Gondolayu Lor, kelompok sosial terbentuk secara tradisional atas dasar kesamaan garis keturunan, pengalaman-pengalaman sosial turun temurun dan kesamaan kepercayaan pada dimensi ketuhanan, cenderung memiliki kohesivitas tinggi tetapi rentang jaringan maupun kepercayaan (trust) yang terbangun sangat sempit (eksklusif). Sebaliknya di Kampung Gambiran, kelompok yang dibangun atas dasar kesamaan orientasi dan tujuan serta dengan ciri pengelolaan organisasi yang lebih terbuka, memiliki tingkat partisipasi anggota lebih baik dan memiliki rentang jaringan lebih luas. Lebih jauh, apabila dilakukan pemisahan bentang modal sosial dalam tiga tipe menurut Woolcock dan Narayan (2000), maka modal sosial dalam gerakan lingkungan Kampung Gambiran dan Gondolayu Lor masuk 
kedalam bridging social capital. Namun yang menarik, modal sosial masyarakat Kampung Gondolayu Lor kembali pada tahap bouding social capital atau modal sosial hanya sebagai pengikat sosial saja. Disisi lain masyarakat Kampung Gambiran telah mencapai tahap linking social capital yang ditandai dengan kemampuan menjalin relasi dengan kekuatan sosial atau semberdaya di luar komunitas.

Modal sosial masyarakat Kampung Gondolayu Lor juga dapat menjadi pelajaran pentingnya memahami kapasitas sosial suatu masyarakat dalam kajian kebijakan publik. Ketidakberfungsian modal sosial masyarakat Kampung Gondolayu Lor dalam gerakan lingkungan seakan mengungkapkan sisi gelap dari modal sosial. Sisi gelap modal sosial atau biasa disebut "the dark side of social capital" (Putnam, 2000), merupakan suatu kecenderungan negatif atas aspek kepercayaan dan jaringan yang dimungkinkan justru menjadi penyebab eksklusifitas sosial suatu komunitas. Hal ini menyebabakan komunitas tidak dapat mengembangkan diri, secara internal tidak dapat mengakses sumberdaya dan secara eksternal tidak dapat mengembangkan jaringan.

Temuan kondisi modal sosial dapat dikatakan kritik dan juga perbaikan atas konsep modal sosial bahwa modal sosial tidak akan berfungsi ketika tidak dikondisikan dalam ruang relasi sosial yang positif, normatif dan menguntungkan. Berpijak pada kritik atas modal sosial itu sendiri, maka sudah seharusnya potensi modal sosial dapat lebih dimanfaatkan dan menjadi fokus dari stakeholder dalam berbagai kebijakan. Penting untuk menilai modal sosial dalam suatu komunitas atau masyarakat sebelum melaksanakan suatu kebijakan, bahkan revitalisasi modal sosial dapat diusulkan menjadi prasyarat dalam kebijakan lingkungan

\section{SIMPULAN}

Berdasarkan hasil penelitian disimpulkan di Kampung Gambiran dapat mencapai keberhasilan perubahan kondisi lingkungan dan Kampung Gondolayu Lor mengalami kegagalan. Kampung Gambiran memiliki berbagai prestasi, ketersediaan fasilitas dan kegiatan lingkungan baik secara swadaya maupun kerjasama dengan berbagai pihak eksternal serta dapat memperluas gerakan lingkungan melalui Forsidas Gajah Wong dan Merti Kampung. Sedangkan Kampung Gondolayu Lor, hanya melakukan pengelolaan sampah dan tidak terintegrasi dalam komunitas Pamerti Code. Identifikasi di kedua kampung tersebut menunjukkan modal sosial sangat 
menentukan dalam gerakan lingkungan. Pengaruh internal dari modal sosial di Kampung Gambiran dapat memobilisasi masyarakat dan dapat mengakses sumberdaya masyarakat seperti, tenaga, waktu, dana, pengetahuan, pengalaman, loyalitas dan sebagainya. Sedangkan Kampung Gondolayu Lor, modal sosial tidak dapat memobilisasi sumberdaya yang dimiliki masyarakat. Pengaruh eksternal terlihat dari kemampuan masyarakat Kampung Gambiran dalam menjalin kerjasama yang luas dengan berbagai stakeholder, hal ini tidak terjadi di Kampung Gondolayu Lor.

\section{DAFTAR PUSTAKA}

Aditjondro, G. J. 2003. Pola-Pola Gerakan Lingkungan: Refleksi Untuk Menyelamatkan Lingkungan dari Ekspansi Modal. Yogyakarta: Pustaka Pelajar

Botetzagias, I and Schuur, W. 2012. "Active Greens: An Analysis of the Determinants of Green Party Members' Activism in Environmental Movements". Environment and Behavior. 509-544.

Bourgon, Jocelyne. 2007. Responsive, Responsible and Respected Government: Towards a New Public Administration Theory. International Review of Administrative Sciences. 726

Broadbent, Jeffrey \& Brockman, Vicky. 2011. East Asian Social Movements Power, Protest, and Change in a Dynamic Region. New York: Springer
Christiansen, J. 2009. Stages of Social Movement. EBSCO Research. Boston: Boston College

Cohen, A, et. al. 2012. "Our Environment, Our Health: A Community-Based Participatory Environmental Health Survey in Richmond, California". Health Education \& Behavior. 198209.

Cronbach, Lee J., et. al. 1985. Toward Reform of Program Evaluation. San Fransisco: Jossey-Bass Publishers.

Della Porta, D. \& Diani, M. 2006. Social Movements: An Introduction (2nd Ed). Malden MA: Blackwell Publishing.

Dwiyanto, A. 2004. Reorientasi Ilmu Administrasi Publik: dari Government ke Governance. Pidato Pengukuhan Jabatan Guru Besar pada FISIPOL UGM

Earle, Lucy. 2011. Literature Review on the Dynamics of Social Movements in Fragile and Conflict-Affected States. University of Birmingham: Governance and Social Development Resource Centre (GSDRC).

Edwards, B. 2013. Social Capital and Social Movements. Oxford: Blackwell Publishing Ltd.

Field, Jhon. 2014. Modal Sosial. Yogyakarta: Kreasi Wacana.

Giddens, Anthony. 2004. Konsekuensikonsekuensi Modernitas. Yogyakarta: Kreasi Wacana

Grootaert, Christiaan \& Bastelaer, Thierry. 2001. Understanding and Measuring Social Capital: A Synthesis of Findings and Recommendations From The Social Capital Initiative. Washington DC: The World Bank

Hasbullah, Jousari. 2006. Social Capital: Menuju Keunggulan Budaya Manusia Indonesia. Jakarta: MR-United Press. 
Haque, M. S. 2001. The Diminishing Publicness of Public Service Under The Current Mode of Governance. Public Administration Review. 65-82

Ife, J \& Tesoriero, F. 2008. Community Development: Alternatif Pengembangan Masyarakat di Era Globalisasi. Yogyakarta: Pustaka Pelajar

Inoguchi T., Newman E., dan Paoletto G. 2003. Kota dan Lingkungan, pendekatan baru terhadap masyarakat berwawaan ekologi. Jakarta: LP3ES.

Kutanegara, Pande. M. 2014. Manusia, Lingkungan dan Sungai (Transformasi Sosial Kehidupan Masyarakat Sempadan Sungai Code). http://cpps.or.id/content/

Lane, Marcus B. 2003. "Participation, Decentralization, and Civil Society: Indigenous Rights and Democracy in Environmental Planing". Journal of Planning Education and Research. 360373.

Laurens, Joyce. M. 2012. Changing Behavior and Environment in a Community-based Program of the Riverside Community. Social and Behavioral Sciences. 372-382. Moulton, S. 2009. Putting Together the Publicness Puzzle: A Framework for Realized Publicness. Public Administration Review. 889-900

Narayan, Deepa and Michael, Cassidy. F. 2001. A Dimensional Approach to Measuring Social Capital: Development and Validation of a Social Capital Inventory. 59-102

Osborne, David dan Gaebler, Ted. 1996. Mewirausahakan Birokrasi (Reinventing Government). Jakarta: Teruna Gravika
Pesch, Udo. 2008. The Publicness of Public Administration. Administration \& Society. 170-193

Pretty, Jules \& Ward, Hugh. 2001. "Social Capital and The Environment". World Development. 209-227

Putnam, R. D. 2000. Bowling Alone: The Collapse and Revival of American Community. New York: Simon \& Schuster.

Santoso, P., Hanif, H., dan Gustomy, R. 2004. Menembus Ortodoksi Kajian Kebijakan Publik. Yogyakarta: Fisipol UGM

Schwartz, M. A. 2010. Interactions Between Social Movements and US Political Parties. Party Politics. 587607.

Sridhar, V. K. 2010. Political Ecology and Social Movements with Reference to Kudremukh Environment Movement". 371-385.

Suharko. 2006. Gerakan Sosial, Konsep, Strategi, Aktor, Hambatan dan Tantangan Gerakan Sosial di Indonesia. Malang: Averroes, PLaCID's \& Simpul Demokrasi.

Sztompka, Piotr. 2011. Sosiologi Perubahan Sosial. Jakarta: Prenada Media.

Utomo, Warsito. 2009. Administrasi Publik Baru. Yogyakarta: Pustaka Pelajar

Woolcock, M \& Narayan, D. 2000. Social Capital: Implications for Development Theory, Research, and Policy. World Bank. 